\title{
Tax Planning, Corporate Governance and Equity Value
}

Nor Shaipah Abdul Wahab and Kevin Holland*

* The authors are respectively Senior Lecturer, PhD, College of Business, Universiti Utara Malaysia, Malaysia and Professor of Accounting and Taxation, School of Management, University of Southampton, UK. Address for correspondence: Nor Shaipah Abdul Wahab, College of Business, Accounting Building, Universiti Utara Malaysia, 06010 Sintok, Kedah, Malaysia.Email: shaipah@uum.edu.my

\section{Acknowledgements}

We appreciate helpful comments from participants at School of Management, University of Southampton Staff Seminar Series; Tax Research Network Annual Conference 2009, Cardiff, Wales; 2010 Hawaii Winter Global Conference on Business and Finance, Hawaii, US; British Accounting Association Annual Conference 2010, Cardiff, Wales; Birmingham Business School Seminar Series 2010, University of Birmingham; and Essex Business School Seminar Series 2011, University of Essex. We would also like to thank both referees for their constructive comments. 


\section{Tax Planning, Corporate Governance and Equity Value}

Abstract: Tax planning by firms is a highly significant activity. After audit fees, tax related services are the largest source of fee income for UK accounting firms. When viewed in terms of its impact, tax planning is the major source of the corporation tax gap amongst large firms (HMRC, 2010). Although traditionally tax planning has been viewed as benefiting shareholders via increased after tax earnings, more recently the underlying motivation has been questioned. Desai and Dharmapala (2006) argue that when an information asymmetry exists between managers and shareholders with respect to tax planning, it can facilitate managers acting in their own interests resulting in a negative association between tax planning and firm value. Using a sample of UK quoted firms from 2005-2007 and data drawn from International Accounting Standard 12 Income Taxes (IASB, 2010) Effective Tax Rate (ETR) reconciliations, this paper reports such a negative relationship. Further, the relationship is robust to the inclusion of corporate governance measures which could be expected to moderate the potential implications of a tax related shareholder-manager information asymmetry. An innovation of this paper is in using the ETR reconciliations to examine sub-categories of tax planning activities. The paper contributes to the debate of who determines, and benefits from tax planning conducted by firms. Its findings have direct policy relevance for shareholders and tax administrations in monitoring and controlling firms' tax planning activities.

Keywords: Tax planning, tax avoidance, firm value, corporate governance, agency costs JEL classification: G14 G30 H20 H32 


\section{Introduction}

Fees for tax services are the most significant source of fee income for UK accounting firms after audit fees (Accountancy, 2007). Typically, such fees amount to 24 per cent of total fee income received by the UK's 60 largest accounting firms (Accountancy, 2007). Whilst some of the advice relates to routine compliance matters it is reasonable to speculate that advice on tax planning comprises a significant element of the fee income. Reliable estimates of the scale of tax planning are notoriously difficult to make primarily due to lack of agreement on definitional and related measurement issues (National Audit Office, 2007). Recently HM Revenue and Customs (HMRC) has published estimates of the "tax gap" i.e. the difference between the theoretical liability and the amount collected. The latest available estimates are for 2008-09 (HMRC, 2010) and show a corporation tax gap of $£ 6.9$ billion, equivalent to $13.9 \%$ of the theoretical liability. For the largest corporate groups administered by its Large Business Service (LBS), HMRC (2010) disaggregates the corporation tax gap into "tax avoidance issues" and "technical issues". In the three year sample frame examined in this paper HMRC (2010) estimates that tax avoidance contributes $77.4 \%, 87.5 \%$ and $92.9 \%$ of the estimated LBS corporate tax gap of $£ 3.1$ billion (2004-05), $£ 3.2$ billion (2005-06) and $£ 2.8$ billion (2006-07) respectively, the balance being attributable to "technical issues" including evasion. These estimates have been criticised for underestimating the extent of the gap and their publication has led to debates on both the actions of tax payers and concerns over the performance of HMRC (Financial Times, 2010). Tax planning is clearly a significant activity both in terms of fees and tax saving.

This paper examines shareholders' valuation of corporate income tax planning. ${ }^{2}$ In the absence of access to confidential tax return data we use the term tax planning to describe all 
activities designed to produce a tax benefit. ${ }^{3}$ Although reducing tax can lead to higher after tax profits there are actual and potential costs that inhibit firms from maximising after tax profits through tax planning. In addition to direct paid costs in the form of salaries and fees, indirect paid costs can arise, for example, when corporate restructuring is a necessary condition for obtaining the desired tax benefit. Potential costs can exist to the extent that tax planning can be challenged by a tax administration which can also then lead to reputational costs. Empirical evidence from the US that suggests tax planning costs act as a significant constraint on corporate tax planning activity may explain what Weisbach (2002) describes as the "undersheltering puzzle" i.e. why firms do not appear to minimise tax liabilities.

More recent US research has suggested further costs, in the form of agency costs, lead shareholders to discount the value of firms by reference to levels of tax planning activity (Desai \& Dharmapala, 2006). They argue the lack of transparency associated with tax planning provides managers with a "screen" or cover to hide self serving actions (Desai et al., 2006). A survey by Henderson Global Investors (2005) found a reluctance on the part of managers to disclose tax related risk management information to shareholders. This lack of awareness on the part of shareholders can lead to information asymmetry between managers and shareholders facilitating moral hazard. A related concern of shareholders is that managers who are "aggressive" with respect to tax planning may also be "aggressive" in their financial reporting decisions (Frank, Lynch \& Rego, 2009). Against this setting it is also relevant to consider the role of corporate governance mechanisms in moderating any relationship between tax planning and firm value (Desai et al., 2006).

Shareholder concerns may also be driven by general attitudes towards tax planning. Since the mid 1990s there is strong evidence of changing attitudes. At the supranational level the 
European Union (EU) and Organisation for Economic Cooperation and Development (OECD) have both acted to protect corporate tax revenues by initially focussing on combating "tax competition" between states (European Union, 1999; OECD, 1998). These initiatives were designed to limit the extent to which individual states could use tax policy to influence firms' location decisions. Subsequently the EU and OECD's focus moved to enhancing legal and administrative procedures to ensure consistent and effective administration of tax legislation. In particular, the European Union (2004) set out steps to improve the ease at which information on corporate tax payers can be passed between tax authorities and non-tax supervisory bodies. In its "Seoul Declaration" the OECD's Forum on Tax Administration announced its intention to study the role of tax intermediaries in "unacceptable tax minimisation arrangements" (OECD, 2008). More recently the OECD (2009) has focused on the banking industry as both a supplier and user of "aggressive tax planning arrangements".

The UK's HMRC has played a leading role in the above initiatives and this is reflected in recent changes within UK tax legislation and tax administration. The Permanent Secretary for Tax at HMRC, David Hartnett, describes 2004 as "a tumultuous year in the tax administration's efforts to counter tax avoidance" (Hartnett, 2009). In that year the HMRC's Anti-Avoidance Group (AAG) was established to develop and deliver the HMRC's antiavoidance activities (Tailby, 2009). Also in 2004 new legislation (The Disclosure of Tax Avoidance Schemes) was enacted to provide HMRC with early information on the marketing of "aggressive" tax planning arrangements (HMRC, 2006). ${ }^{4}$ A change of approach has also been adopted in implementing existing legislation with the HMRC's use of risk assessments to direct administrative effort to examining firms where the estimated level of corporate tax risk is highest (Freedman, Loomer \& Vella, 2007; HMRC, 2007). 
Tax planning by firms is of wider public interest since it can affect the level of provision of public goods which can then contribute to social issues (Slemrod, 2004). Non-Governmental Groups in the UK such as Oxfam (2009), Christian Aid (2009) and Trade Union Congress (2009) have all examined the issue from a social justice perspective. A similar line was taken by The Guardian (2009) in a series of newspaper articles.

The measure of "tax planning" used in this paper is initially defined as the difference between a firm's current tax provision as disclosed in its annual financial statements and the (notional) level of tax that would be payable if its profit before tax was subject to tax at the UK statutory rate. We accept this is an imperfect measure of the outcome of tax planning activities for a number of reasons. Firstly, the measure would fail to detect tax planning that results in income not being subject to tax whilst also being excluded from accounting income. As discussed below strong incentives act against this scenario. Secondly, the measure includes non-discretionary differences between accounting and tax definitions of income which do not necessarily represent tax planning. These include for example, timing effects arising from differences between accounting depreciation and capital allowance rates or permanent effects arising when capital expenditure does not qualify for capital allowances. In subsequent analysis the sensitivity of the paper's conclusions to these limitations is assessed.

The paper's contribution is four fold. Firstly against a backdrop of increased attention on firms' tax planning activities it provides the first evidence concerning shareholder valuation of UK firms' tax planning and provides insights into corporate behaviour and the resulting response of shareholders. The extant literature is US based and does not necessarily translate to the UK setting because of differences in tax law and approaches to compliance and enforcement. Secondly by using recently available tax reconciliation data required under IAS 
12 Income Taxes (IASB, 2010), this paper uses disaggregated tax related data to test for differential effects of varying types of tax planning. Previous studies have generally relied on a lower level of disaggregation e.g. Desai and Dharmapala (2009). Thirdly although the potential moderating influence of corporate governance on the relationship between tax planning and share value has been examined in earlier studies, factor analysis is used to generate proxy variables that capture broad over reaching corporate governance structures. This avoids a subjective choice of proxy variables. Fourthly the analysis is conduced over a three year period thereby recognising that the composition of tax planning activities and attitudes to tax planning may vary over time.

In summary we find evidence of a negative relationship between the level of tax planning and firm value. When its components are analysed separately, the source of the negative relationship appears to be permanent differences between taxable income and accounting profit measures. Both these findings are consistent with the Desai et al. (2006) agency view of tax planning. Unlike US studies though there is no compelling evidence of the negative relationship being moderated by corporate governance procedures.

The next section of the paper reviews the relevant literature and is followed by sections on research design, sample and data source, results, further analysis and finally the conclusion.

\section{Tax planning activities, corporate governance and shareholders' valuation}

Whilst there is a relatively long tradition of research in documenting and explaining variations in tax burdens or Effective Tax Rates (ETRs) in terms of firm level characteristics e.g. Zimmerman (1983), Gupta and Newberry (1997) and Holland (1998), only recently has attention turned to understanding the underlying motivation for these variations and any 
potential equity valuation consequences. Traditionally, tax planning is seen as leading to increased after tax earnings and therefore to be in the interest of shareholders; this is the view typically taken in valuation models. In recognising shareholders' need to control managers' tax decision making, Slemrod (2004) suggests linking managers' compensation to "desirable outcomes" such as ETR. This implied valuation effect is consistent with anecdotal evidence of a negative association between ETR and share price (Swenson 1999).

Studies of tax related valuation effects have considered whether in making valuation assessments shareholders differentiate between different categories of tax planning in terms of expected benefits and costs including risk. These studies typically use deferred tax disclosures in firms' annual statements to disaggregate tax planning activities. IAS 12 Income Taxes (IASB, 2010) requires firms to provide a breakdown of their tax charge distinguishing between current and deferred taxes. A deferred tax charge (credit) is required when an item of income or expense included in the current income statement is included in the taxable income calculation of another period i.e. a "timing difference" (IASB, 2010). For example, differences in the rates of accounting depreciation and capital (investment) allowances with respect to qualifying capital expenditure. ${ }^{5}$ Consequently, the tax charge in the income statement includes both the current and future (deferred) tax consequences of the current period's activities. ${ }^{6}$ In contrast, income or expenses which are only ever included in either the current income statement or the current taxable income calculation give rise to what are commonly referred to as "permanent differences".

Consequently planning benefits can be classified as either permanent or timing although in practice the distinction between the two can be blurred where timing differences are continually replaced. US evidence of the nature of tax planning suggests that "tax shelter" 
activity is directed at permanent savings (Wilson, 2009). In contrast, although deferral or timing differences have no impact on the overall tax expense in the income statement a cash flow timing benefit can arise (Maydew \& Shackelford, 2007).

In examining valuation effects of timing and permanent differences it is necessary to control for earnings management as it can give rise to similar differences (Phillips, Pincus \& Rego, 2003; Hanlon, 2005). Further, in attributing differences to tax planning activity, it is necessary to isolate non-discretionary items e.g. tax depreciation, which although potentially having a valuation effect, do not necessarily represent tax planning activity (Frank et al., 2009).

In the literature on potential tax related valuation effects two specific sources of differences have been examined. Amir and Sougiannis (1999) and Atwood and Reynolds (2008) find that current period utilisation of prior period tax losses is value relevant. Similarly where a firm operates across a number of jurisdictions with varying statutory rates, tax rate differentials can provide a tax saving recognised in firm value (Bauman \& Shaw, 2008). The valuation of the tax rate differential is dependent on the perceived earnings repatriation policy and the relative stabilities of the tax jurisdictions involved, i.e. whether the effect represents a timing or de facto permanent difference.

In contrast, some studies find no direct association between measures of firm value and tax planning related measures. This absence has been attributed to the effect of unquantifiable non-tax costs (Cloyd, Mills \& Weaver, 2003). ${ }^{7}$ In particular Desai et al. (2006) predict that in an agency setting tax planning can lead to a reduction in firm value when managers have both the opportunity to understate reported accounting profit and the incentive to reduce corporate 
income tax liability by understating taxable income. If the two forms of understating are complementary, the general lack of transparency associated with tax planning provides "cover" for managers to extract rents at the expense of shareholders by understating accounting profit. Further, the effect of this complementary relationship is conditional upon the corporate governance mechanisms in place. Desai et al. (2006) predict that tax planning will be valued negatively by shareholders where weak corporate governance would permit associated understatement of accounting profit. When corporate governance provision is strong, accounting profit understatement is not possible and therefore tax planning provides no diversionary benefit. Desai et al. (2009) provide empirical evidence which gives some support for the prediction that corporate governance moderates the relationship between tax planning and firm value. This finding is consistent with the conclusion that tax planning is interpreted to have been conducted for the benefit of shareholders only when the level of corporate governance is strong. In other cases shareholders appear to be suspicious of managers' motives and do not value tax planning positively. Similarly, Wilson (2009) and Hanlon and Slemrod (2009) document evidence that shareholders' valuation of tax planning activity is conditional upon corporate governance status. A related valuation effect contributing further to shareholders' potential concerns is that "aggressiveness" in tax planning can be associated with accounting "aggressiveness" (Frank et al., 2009). Within the same accounting period firms attempt to manage accounting profit upwards while simultaneously managing taxable income downwards. 


\section{Research design}

\section{Measurement of tax planning}

As shareholders do not generally have access to firms' tax returns and details of their planning activities it is necessary to use proxies based on publicly available information (Stewart, 1981). In addition to the requirement to provide for deferred taxation IAS 12 Income Taxes (IASB, 2010) requires firms to publish a reconciliation between the actual tax expense and the notional expense arising if liability was based on the current accounting profit before tax, i.e. without the adjustments normally required under tax law to convert accounting profit to taxable income. We measure the extent of tax planning as the after tax (net) effect of any difference between accounting profit and taxable income i.e. the sum of permanent differences (PD) and timing differences (TD). ${ }^{8}$ As discussed previously this measures captures both the effects of tax avoidance and any tax evasion. Hence we use the more general term "tax planning" (TP) to describe the measured effect. In addition to permanent and timing differences, variation between the notional and actual tax expense can arise when a firm faces varying statutory rates because of taxable income arising in more than one tax jurisdiction. Using published ETR reconciliations this statutory rate differential (STRDIF) can be separately identified.

The variable TP is defined in equation 1 below and as shown is equivalent to the difference, in profit terms, between a firm's statutory tax rate and its ETR. ${ }^{9}$ This ETR measure is consistent with that used in prior studies which have examined equity considerations, for example Zimmerman, 1983; Porcano, 1986; Holland, 1998; Mills, Erickson and Maydew, 1998; Rego, 2003; Dyreng, Hanlon and \& Maydew, 2008.

$$
T P=S T R_{u k} *(P D+T D)+S T R D I F=P B T *\left(S T R_{u k}-\frac{C T E}{P B T}\right)
$$


Where: $\mathrm{TP}=$ tax planning measure, $\mathrm{STR}_{\mathrm{uk}}=\mathrm{UK}$ statutory main corporation tax rate, $\mathrm{CTE}=$ current tax expense, $\mathrm{PBT}=$ profit before tax, $\mathrm{PD}=$ permanent differences between accounting profit and taxable income measures, $\mathrm{TD}=$ timing differences between accounting profit and taxable income measures and STRDIF $=$ tax effect of differences between UK and non UK statutory corporate income rates. The value of STRDIF is disclosed in published ETR reconciliations and can be defined as in equation 2:

$\mathrm{STRDIF}=\left(\mathrm{STR}_{\mathrm{uk}}-\mathrm{STR}_{\mathrm{OS}}\right) * \mathrm{TP}_{\mathrm{OS}}$

Where: $\mathrm{STR}_{\mathrm{OS}}=$ weighted (by taxable income) average overseas statutory corporate income tax rate and $\mathrm{TP}_{\mathrm{OS}}=$ taxable income subject to overseas tax.

A potential limitation of the tax planning variable is that it fails to detect tax savings that do not generate either a timing difference, permanent difference or result in a reduced statutory tax rate applying, as captured by the variables, TD, PD and STRDIF respectively. This could arise where income is legally or illegally excluded from the income statement. Academic evidence suggests that such exclusion is unlikely to be significant; the need to report sufficient level of accounting profit in order to satisfy capital market expectations is a significant constraint on tax planning strategies (Hanlon, 2003).

The tax planning variable (TP) is designed to capture the aggregate effect of tax planning activity. As discussed above its individual components may have varying valuation effects. Using the IAS 12 Income Taxes (IASB, 2010) reconciliations subsequent analysis classifies reconciling items into four categories comprising: permanent differences (TPD), timing 
differences excluding loss relief (TTD), loss relief (TLOSS) and where the description of a reconciling item was insufficient to make a classification on the above basis, unclassified (TUNC). The reconciliations also disclose the effect of differences in statutory tax rates (STRDIF). These disclosures allowed for the disaggregation of the PD and TD terms in the tax planning variable TP in equation (1) into these further components as follows in equation 3:

$\mathrm{PD}+\mathrm{TD}=\mathrm{TPD}+\mathrm{TTD}+\mathrm{TLOSS}+\mathrm{TUNC}$

\section{Measurement of corporate governance}

In preference to using selective individual factors to capture broad corporate governance mechanisms factor analysis is used to systematically identify proxies of underlying corporate governance constructs. To ensure the relevance of the selection process the full range of variables was selected from two recent studies of UK corporate governance practice by Florackis (2008) and McKnight and Weir (2009). The mechanisms considered represent ownership structure, board structure and compensation structure, see table 1 .

\section{Insert Table 1 about here XXX}

Ownership structure focuses on managerial and institutional ownership as potential mechanisms to reduce agency conflict. However, previous studies of managerial ownership document both a positive effect through goal congruence (Jensen \& Meckling, 1976) and negative effect, at high levels of ownership, through entrenchment (Florackis, 2008). Similarly, although institutional shareholders can provide an informed monitoring function, UK institutional shareholders are generally found to be passive (Goergen \& Renneboog, 
2001). Further, high levels of institutional ownership might allow a dominant institution to pursue its own objectives at the expense of other shareholders (Hart, 1995).

Board structure defined in terms of the proportion of non-executive directors to total directors, board size and duality of chair and chief executive can be a significant factor in influencing shareholder - manager relationships (Florackis, 2008). ${ }^{10}$ Non-executive directors have been found to be effective in mitigating agency problems due to the constructive effects of directors' independence, professional knowledge and experience (Zahra \& Pearce, 1989). Board size has been found to influence corporate governance effectiveness in both positive and negative ways. Positively, large size can be associated with an increased range of skills and experience, greater opportunities in securing resources and more effective restriction of CEO domination. However, large size can also be associated with increased complications in coordination, communication and decision-making processes (Florackis, 2008). Individual directors holding multiply directorships have been found to provide increased effectiveness in terms of access to social networks, knowledge spillovers from multiple backgrounds and higher commitment of directors (Conyon \& Muldoon, 2006; Haniffa \& Hudaib, 2006).

Finally, compensation structure is considered. This mechanism, either by way of granting share options or providing performance-related pay, is designed to align managers' interests with those of shareholders (Florackis, 2008). However, the effectiveness of remuneration in reducing agency related problems can be challenged (Firth, Tam \& Tang, 1999). Following Florackis (2008), this paper considers variables based on the level of executive salary and a dummy variable to capture the presence of options or performance related bonuses. 
Before applying factor analysis, an initial assessment of the characteristics of the underlying data was performed. This comprised three steps: analysis of the pearson correlation matrix of the corporate governance variables, examining its determinate and measuring sample adequacy using the Kaiser-Meyer-Olkins test (KMO) and Bartlett's test of sphericity (Pett, Lackey \& Sullivan, 2003). These test statistics are reported in table 2 (panel A). The insignificant determinate and Bartlett test values combined with an overall KMO test value of 0.6115 support the use of factor analysis. ${ }^{11}$ Finally, as all but two of the correlation coefficients are significant at the 5\% level and all of the KMO statistics are in excess of 0.5 (see table 2, panel B) it is concluded that factor analysis can be applied to the data set.

\section{Insert Table 2 about here XXX}

The factor analysis indicate two underlying factors with eigenvalues $>1$, and a cumulative variance explanation of 0.5111 , as shown in table 2 (panel C). ${ }^{12}$ As the factor analysis is conducted with the intention to derive general corporate governance variables, a surrogate variable is required (Hair, Black, Babin, Anderson \& Tatham, 2006). Thus, all of the items are further analysed to determine surrogate variables for each of the two factors. Based on the highest factor loadings the results indicate the proportion of non-executive directors on the board of company (NED) and percentage of shares held by substantial institutional shareholders (IOWN) as surrogates of factor 1 and 2 respectively in capturing firms' general corporate governance structures. Consequently, these two variables are included in the subsequent empirical analysis.

\section{Regression models}

The empirical analysis in this paper is based on a standard valuation model used in the accounting literature, for example, O'Hanlon and Taylor (2007) and Horton (2008). The 
model explains equity valuation as a function of book value (BV) and current earnings (PBT) and a series of control variables. Market (firm) value of equity (MVE) is measured three months after the accounting year-end to reflect the lag in disclosing annual financial statements to shareholders (O'Hanlon \& Taylor, 2007; Horton, 2008). ${ }^{13}$

The control variables mainly relate to information asymmetry and agency costs, for example, annual dividends (DIV) (Rees, 1997) and capital contribution (CC) (Akbar \& Stark, 2003). In line with valuation relevance and taxation literatures, this paper also controls for several firmspecific characteristics, these consist of capital intensity (CAPINT) (Mills et al., 1998; Frank et al., 2009), industry type (INDDUM) (Derashid \& Zhang, 2003; O'Hanlon et al., 2007), leverage (LEV) (Mills et al., 1998), foreign sales (FS) (Rego, 2003; Bauman et al., 2008) and earnings management (EM) (Healy, 1985; Phillips et al., 2003; Hanlon, 2005).

In explicitly controlling for observable tax related proxies of tax planning activities e.g. CAPINT, LEV and FS, the tax planning variable TP captures tax planning in other undefined areas which, because of their relative lack of transparency when compared to capital structure for example, may be valued differently by shareholders (Chen, Chen, Cheng \& Shevlin, 2010). A subsequent version of the model is run without the inclusion of these three control variables. The initial model (I) incorporating the tax planning and related control variables is set out below with variables as defined in table 3:

$$
\begin{aligned}
& M V E_{i t+3}=\beta_{0}+\beta_{1} B V E_{i t}+\beta_{2} P B T_{i t}+\beta_{3} T P_{i t}+\beta_{4} C C_{i t}+\beta_{5} E M_{i t}+\beta_{6} C A P I N T_{i t} \\
& +\beta_{7} L E V_{i t}+\beta_{8} D I V_{i t}+\beta_{9} F S_{i t}+\sum_{n=10}^{16} \beta_{n} I N D D U M_{i t}+\varepsilon_{i t}
\end{aligned}
$$


To assess the potential effect of corporate governance factors on the valuation of tax planning the above model is extended by including the two corporate governance related variables NED and IOWN to give model II as follows:

$$
\begin{aligned}
& \text { MVE }_{i t+3}=\beta_{0}+\beta_{1} B V E_{i t}+\beta_{2} P B T_{i t}+\beta_{3} T P_{i t}+\beta_{4} N E D_{i t}+\beta_{5} I O W N_{i t}+\beta_{6} C C_{i t}+\beta_{7} E M_{i t} \\
& +\beta_{8} C A P I N T_{i t}+\beta_{9} L E V_{i t}+\beta_{10} D I V_{i t}+\beta_{11} F S_{i t}+\sum_{n=12}^{18} \beta_{n} I N D D U M_{i t}+\varepsilon_{i t} \quad \text { (model II) }
\end{aligned}
$$

A third model (III) tests whether the relationship between firm value and tax planning is moderated by the strength of firms' corporate governance structures. Accordingly, model III is extended by the inclusion of two moderating variables, TP*NED and TP*IOWN constructed by multiplying a firm's tax planning variable by NED and IOWN variables respectively.

$$
\begin{aligned}
& \mathrm{MVE}_{i t+3}=\beta_{0}+\beta_{1} \mathrm{BVE}_{i t}+\beta_{2} \mathrm{PBT}_{i t}+\beta_{3} \mathrm{TP}_{i t}+\beta_{4} \mathrm{NED}_{i t}+\beta_{5} \mathrm{IOWN}_{i t}+\beta_{6} \mathrm{TP}_{i t}{ }^{*} \mathrm{NED}_{i t}+ \\
& \beta_{7} \mathrm{TP}_{i t}{ }^{*} \mathrm{IOWN}_{i t}+\beta_{8} \mathrm{CC}_{i t}+\beta_{9} \mathrm{EM}_{i t}+\beta_{10} \mathrm{CAPINT}_{i t}+\beta_{11} \mathrm{LEV}_{i t}+\beta_{12} \mathrm{DIV}_{i t}+\beta_{13} \mathrm{FS}_{i t}+ \\
& \sum_{n=14}^{20} \beta_{n} \mathrm{INDDUM}_{i t}+\varepsilon_{i t}
\end{aligned}
$$

In each of the above models the aggregate tax planning variable TP has been employed. To test whether shareholder valuations of tax planning are conditional on the nature of the tax planning, in model IV the variable TP is replaced by its individual components TLOSS, TPD, TTD, STRDIF and TUNC as follows: 


$$
\begin{aligned}
& \text { MVE }_{i t+3}=\beta_{0}+\beta_{1} \mathrm{BVE}_{i t}+\beta_{2} \mathrm{PBT}_{i t}+\beta_{3} \mathrm{TLOSSS}_{i t}+\beta_{4} \mathrm{TPD}_{i t}+\beta_{5} \mathrm{TTD}_{i t}+\beta_{6} \mathrm{STRDIF}_{i t} \\
& +\beta_{7} \mathrm{TUNC}_{i t}+\beta_{8} \mathrm{NED}_{i t}+\beta_{9} \mathrm{IOWN}_{i t}+\beta_{10} \mathrm{CC}_{i t}+\beta_{11} \mathrm{EM}_{i t}+\beta_{12} \mathrm{CAPINT}_{i t}+\beta_{13} \mathrm{LEV}_{i t}+ \\
& \beta_{14} \mathrm{DIV}_{i t}+\beta_{15} \mathrm{FS}_{i t}+\sum_{n=16}^{22} \beta_{n} \mathrm{INDDUM}_{i t}+\varepsilon_{i t}
\end{aligned}
$$

\section{Insert Table 3 about here XXX}

Each of the four models is deflated to control for any scale effects (Stark \& Thomas, 1998; Akbar \& Stark, 2003). In the absence of a theoretical justification on how to control for such effects a number of alternate deflators are used; opening book value of equity, opening market value of equity, number of shares and sales (Rees, 1997; Liu \& Stark, 2009). In line with existing literature our main results are based on the opening book value of equity deflator. The models were estimated using the Stata econometric software. The reported results are based on a random-effects estimation, subsequent sensitivity analysis reports results based on a fixed effects estimation to capture firm specific characteristics.

\section{Sample and data}

The paper employs a panel dataset of firms listed on the London Stock Exchange during the three year period 2005-2007 restricted to non-financial firms because of the limitations of using accounting based valuation models on financial firms. As the nature of tax planning activities may depend on firms' expectations about future levels of profitability, with consistently profitable firms having a stronger incentive for tax planning (Mills et al., 1998), the sample is limited to firms that were profitable in all three years of the sample frame. ${ }^{14}$ Further filters were used to exclude firms with negative book value, necessary as this variable is used as a deflator, negative tax charge, insufficient data and extreme ETRs. Table 4 
presents the sample selection process which resulted in 196 firms to give a balanced panel of 588 year end observations over the three year period.

The dataset comprised tax data extracted from firms' annual reports with the remaining financial statement related data obtained from Thompson Financial Datastream. Corporate governance data was obtained from Hemscott database with supplemental data collected from annual reports and The Corporate Register (various years).

\section{Insert Table 4 about here XXX}

\section{Descriptive statistics}

When estimating the above models influential and outlying observations were excluded to provide a more representative analysis. ${ }^{15}$ Table 5 contains descriptive statistics relating to the resulting sample of 444 firm year end observations used in estimating models I, II and III and the sample of 405 year end observations used to estimate model IV. Based on table 5 the mean value of TP indicates a mean tax saving of $£ 7.465 \mathrm{M}$ for the sample of 444 firm year ends and a corresponding figure of $£ 7.377 \mathrm{M}$ for the smaller sample of 405 firm year ends. The relative magnitude of the tax planning components can be seen in table 5. Expressed as a percentage of mean profit before tax the individual components in order of declining magnitude are: TTD (1.32\%), STRDIF (0.59\%), TUNC (0.53\%), TLOSS (0.40\%) and TPD $(-0.19 \%)$. For each of the five components there are both positive (tax saving) and negative (tax increasing) values which highlights the dynamic nature of tax planning. The relatively high value of TUNC raises questions about the sufficiency of some firms' tax related disclosures. 
The corporate governance related characteristics of the sample can be summarised as follows: the mean board size (BSIZE) is eight directors with a slight majority (57\%) being nonexecutive directors (NED). Consistent with the observation that non-executive directors provide networking related benefits the percentage of directors that have multiple directorship (MDIR) is almost half (49\%). Directors' equity ownership (DOWN) is typically $7 \%$ while the level of institutional ownership (IOWN) is higher at $34 \%$. The mean basic salary compensation (SAL) per board for executive directors in total is $£ 987,577$. These values are similar to those reported in a recent UK corporate governance study (Florackis, 2008) with the exception of DOWN which was higher at $15 \%$.

\section{Insert Tables 5 about here XXX}

\section{Results}

The results of the four models are reported in table 6. In addition to the influential and outlier analysis previously described, further diagnostic tests were performed. The level of multicollinearity was assessed using condition indices (Belsley, Kuh \& Welsch, 1980). These indicated the levels were acceptable. ${ }^{16}$ Due to repeated sampling of firms that have common features e.g. year end, panel data in accounting research can exhibit serious cross-sectional (“clustering”) dependence (Bernard, 1987; Petersen, 2009). Consequently the reported standard errors are estimated using Eicker-Huber-White robust standard errors which also control for heteroscedasticity (Petersen, 2009).

\section{Insert Table 6 about here XXX}


Models I, II and III are reported in columns I, II, III of table 6. The first two models show a significant negative relationship between firm value and tax planning which is robust to controlling for corporate governance mechanisms in model II. ${ }^{17}$ This result is consistent with shareholder concerns about moral hazard risk in tax or other tax planning-related risks, for example, the risk related to inspection or investigation by tax authorities. The negative significant coefficient with respect to IOWN is consistent with the Goergen et al. (2001) finding on the passive and ineffective monitoring role played by UK institutional investors. The control variables where significant are of the expected negative sign in the cases of EM and CAPINT. The variable FS is positive suggesting that an increasing proportion of non UK sales is associated with higher firm value. Though this result could be explained by differences in relative tax rates it could also arise because of differences in relative profitability. In model IV we explicitly test for the effect of foreign tax rate differentials.

Model III incorporates the two moderating variables TP*NED and TP*IOWN to examine whether the relationship between firm value and tax planning is conditional upon the strength of corporate governance structures. The previously negative significant relationship between firm value and tax planning no longer holds, and although now positive, TP is not significantly different from zero. Caution should be exercised in interpreting this as evidence of a corporate governance effect. A comparison of the adjusted $\mathrm{R}^{2}$ for model III $(64.70 \%)$ with that of model II $(64.34 \%)$ is consistent with the moderating corporate governance variables $\mathrm{TP} * \mathrm{NED}$ and $\mathrm{TP} * \mathrm{IOWN}$ contributing little in terms of additional explanatory power. ${ }^{18}$ As an additional test of the influence of corporate governance the sample was split into sub-samples of "high" and "low" corporate governance effectiveness (Desai et al., 2006). Firms were assigned a sub-sample by reference to the median value of the product of NED and IOWN on the basis that both higher institutional ownership and proportion of non- 
executive directors could contribute to better corporate governance (Zahra et al., 1989; Florackis, 2008). The results are reported in the next two columns of table 6 for "high" and "low" governance firms respectively. Both estimations report a significant negative relationship between firm value and TP; the TP coefficients in the two sub samples do not significantly differ from each other. ${ }^{19}$ In contrast to Desai et al. (2009), these results suggest corporate governance does not mitigate the negative relationship between TP and firm value even in the case of "high" governance firms. ${ }^{20}$

The next set of results examines whether the relationship between TP and firm value varies by its components (model IV). There is a significant negative relationship between firm value and TPD. Despite controlling for earnings management through the variable EM, it is possible that the variable TPD reflects both tax planning and earnings management (aggressive accounting). However, a comparison of the EM coefficient between models II and IV which exclude and include the variable TPD respectively shows an insignificant difference consistent with TPD reflecting tax effects. ${ }^{21}$ The remaining tax planning components TLOSS, TTD, STRDIF and TUNC are statistically insignificant. ${ }^{22}$ Although the variable FS which measures the proportion of firm sales that are made outside of the UK is consistently positive and statistically significant, the foreign tax rate differential variable STRDIF is consistently insignificant, though positive. This suggests the influence of FS is derived from pre tax profitability and not tax benefits.

\section{Further analysis}

This section reports further analysis to assess the robustness of the above results. The analysis relates to the date of measuring firm value, choice of deflator, firm fixed-effects, potential 
non-linear association between firm value and tax planning, alternative measures of firm value and the exclusion of the potential tax planning related control variables. To provide a fuller picture of the association between firm value and tax planning, annual regressions are also carried out.

Qualitatively identical results to those reported above in models I, II and III are found when deflating either by opening market value of equity or sales. However, when deflating by number of shares no significant relationship is found between tax planning and firm value. When examining the individual components using model IV deflated by the number of shares TPD is no longer significant while STRDIF become significant and positive. When opening market value is used as the deflator, none of the components in model IV are reported as significantly related to firm value. When deflated by sales the only significant component is TTD which becomes positive. Caution must therefore be exercised in attributing the source of the overall negative relationship between firm value and tax planning to individual components because of the sensitivity of model IV's results.

The results reported in table 6 are estimated using a random effects model which assumes any uncontrolled heterogeneity in firm specific factors are not correlated with the included independent variables. We relax this assumption through the use of a fixed effects model. These results are qualitatively no different from those in table 6 . We conclude that the negative relationship between firm value and TP does not appear to be proxying for omitted firm specific characteristics, such as earnings management.

High levels of tax planning may only be achievable at unacceptable levels of risk or "aggressiveness". Consequently the negative association between firm value and TP may 
increase non-linearly at "higher" levels of tax planning (Hanlon et al., 2009). Models I and II were re-estimated with the inclusion of quadratic tax planning variable TPNL defined as TP*TP. The inclusion of this variable did not change the previously reported results and did not significantly increase the models explanatory power consistent with a linear relationship.

Tobin's Q has been used in some studies e.g. Desai et al. (2009) as an alternate dependent variable to market value of equity. ${ }^{23}$ Regressing Tobin's Q onto the independent variables in models I, II and III produce qualitatively identical coefficient estimates to the results in table 6. When using Tobin's Q to examine the individual components in Model IV, in contrast to the significant negative relationship reported in table 6 for TPD, no statistically significant coefficient arises with respect to TPD or any of the other tax component variables.

The inclusion of the control variables CAPINT, LEV and FS which are designed to capture observable tax planning related activities result in the variable TP capturing the remaining or unobservable tax planning activities (Chen et al., 2010). Omitting these three variables from the models would result in the variable TP capturing a wider range of tax planning activities both observable and unobservable. To the extent that observable activities pose lower risks to shareholders in terms of moral hazard etc, the TP coefficient should increase after excluding the three control variables with similar effects for the individual components in model IV. However, these revised models show qualitatively identical results to those reported in table 6., in particular there are no significant differences with respect to the TP variable or its components. $^{24}$ This implies the negative TP coefficient and those of the individual tax components are not solely driven by unobservable tax planning related factors but that shareholder concerns relate to both observable and unobservable tax planning factors. 
Attitudes to tax planning have changed over time as discussed above. To explore the possibility that the negative relationship between firm value and tax planning may vary over time two further tests were conducted. Firstly models I, II and III were reestimated with the inclusion of year dummies, this process has no effect on the qualitative interpretation of the reported results. Secondly annual regressions for each of the three years were estimated. The results for 2005 and 2006 are consistent with the above results, while for 2007 a statistically insignificant coefficient is reported for $\mathrm{TP} .^{25}$

The variation in annual results suggests changes over time in either the nature of tax planning or shareholders' attitudes to tax planning, or a combination of both effects. Given the restrictions of using publicly available data relating to tax planning it is difficult to assess the extent to which the first factor is valid. However, an investigation of the individual components by year does reveal variation in their relative importance. Figure 1 plots by year the mean value of each component relative to TP. Of particular note is the reversal between 2005 and 2006 of the relative importance of TPD and TTD and the marked variation in the remaining terms with the exception of TLOSS. This adds strength to the need to consider several years of data when drawing conclusions on tax planning effects because of possible linkages between years. Though there is considerable variation across the years there is no obvious indication of why 2007 differs from the earlier two years.

\section{Insert Figure 1 about here XXX}

\section{Conclusions}

Our overall conclusion is that tax planning is not valued by shareholders and is in fact value reducing. A consistent negative relationship between tax planning and firm value arises 
which is generally robust to a number of different specifications and controls. On average the results are consistent with an agency cost theory of tax planning where the information asymmetry generally associated with tax planning can result in moral hazard or fear of moral hazard. There is some evidence that suggests the source of the negative relationship to be permanent differences, where income is included in accounting profit but falls outside the definition of taxable income. Arguably this type of activity although carrying the highest potential tax benefits also potentially generates the highest level of risk and cost.

This overall result is consistent with some of the prior exclusively US based research. However, in contrast to US findings of Desai et al., (2009) and Wilson (2009), corporate governance mechanisms do not appear to moderate the agency costs associated with tax planning. Two possible explanations exist, firstly UK corporate governance mechanisms are ineffective per se, or secondly, there is insufficient tax related information made available for a potential control mechanism to operate and this deficiency is noted by shareholders. These differences suggest researchers should pay attention to tax related institutional and policy differences that exist between countries when interpreting existing research.

In considering the results it is again worth emphasising that the tax planning measure uses only publicly available information which although identical to the position shareholders are in may result in misstatement. If shareholders are to be effective monitors and controllers of firms' tax related decision, financial reporting and tax regulatory bodies should consider requiring increased tax related disclosures by firms. However, shareholders face a dilemma if in demanding increased tax related disclosure managers are discouraged from pursuing "legitimate" tax planning activities. To the extent that increased disclosure reduces "illegitimate" activity shareholders and tax administrators would benefit. A critical step in 
determining the extent and form of additional disclosures is agreeing the boundary between "legitimate" and "illegitimate" tax planning. 
Notes:

${ }^{1}$ HMRC (2010) defines technical issues as "uncertainty about the correct tax treatment, through mistakes to culpable errors in, or omissions from, the company tax return". This definition would therefore include the effects of tax evasion.

${ }^{2}$ All subsequent references to tax are to corporate income tax unless otherwise stated.

${ }^{3}$ Using only publicly available information replicates the position facing shareholders and therefore distinctions between (legal) tax avoidance and (illegal) tax evasion and intermediary concepts such as "acceptable tax avoidance" and "aggressive tax planning" cannot be made. In recognition of this we use the term tax planning to describe the observed effects though, as subsequently discussed, we would expect tax avoidance to be the main form of tax planning. Earlier studies that use the term tax avoidance make an implicit assumption as to the legality of the underlying tax planning processes. However, when referring to official reports we use the terminology adopted in the report for the sake of consistency.

4 More recently the Government has established a "study programme" to establish the feasibility of introducing a "General Anti-Avoidance Rule" (GAAR) into UK domestic legislation (HM Treasury, 2010).

${ }^{5}$ Other sources of timing differences include such items as product warranty costs, retirement benefit costs and research costs which can be deducted from accounting profits on an accrual basis but are only deductible for tax purposes when paid in a subsequent period (IASB, 2010). The deferred tax charge can also be affected by a timing difference in relation to unused tax losses (IASB, 2010).

${ }^{6}$ In addition to timing differences recognised in the income statement IAS 12 also requires recognition of temporary differences arising from differences between an asset or liability's (revalued) carrying value for accounting purposes and its tax base. Such temporary differences are recognised outside the income statement and therefore the measure of tax planning in this paper is free of tax related revaluation effects.

7 The measurement problem presented by non-tax costs when attempting to identify tax effects has been highlighted by Shackelford and Shevlin (2001) and Chen, Chen, Cheng and Shevlin (2010). 
${ }^{8}$ In contrast an alternative measure of tax planning, the "book-tax gap", captures the gross effect of the differences between accounting profit and taxable income. The use of a net or ETR based measure as used in this study has the advantage that it can avoid measurement errors in the process of grossing up foreign tax expenses in order to arrive at the level of (gross) taxable income (Hanlon, 2003).

${ }^{9}$ Where the ETR expresses the current income tax expense (CTE) relative to the accounting profit before tax (PBT). Using the notation in the following paragraph CTE is defined as: $\mathrm{CTE}=\mathrm{STR} *(\mathrm{PBT}-\mathrm{PD}-\mathrm{TD})$.

${ }^{10}$ In the sample used in this paper $98 \%$ of the observations have separate Chair and CEOs. Therefore the issue of duality is not considered further.

${ }^{11}$ The KMO test value is in excess of the acceptable threashold level of 0.5 (Hair et al., 2006). 12 The loadings are based on an orthogonal varimax rotation method in which the factors are assumed to be independent of each other. However, analysis based on an alternative rotation, i.e. promax rotation, is also conducted and the results are qualitatively similar to the loadings of varimax rotation.

13 The subsequently reported results are robust to measuring the market value of equity six months after the year-end. This alternative measurement of market value allows a longer period for information in the annual financial report to be reflected in the share price (Rees, 1997; Stark \& Thomas, 1998; O'Hanlon \& Pope, 1999).

14 This restriction resulted in the exclusion of 22 non-persistent firms. This number is insufficient to conduct tests within this subset of firms.

${ }^{15}$ The basis for excluding influential observations is the DFIT measure, its critical value is: abs $(\mathrm{DFIT})>2 *(\mathrm{P} / \mathrm{N})^{1 / 2}$ where $\mathrm{P}$ and $\mathrm{N}$ are the number of variables and observations respectively (Belsley et al., 1980). Outlying observations were defined with a studentized residual $>|2|$ (Chen, Ender, Mitchell \& Wells, 2005). In models I, II and III, 87 year end observations were excluded as either influential or outlying respectively. In order to maintain a balanced panel by necessity a further 57 year end observations were excluded. In model IV the number of firm year ends excluded was 99 and 84 respectively.

16 None of the condition indices exceed the critical value of 30 (Belsley et al., 1980). Similarly bivariate correlation analysis shows an acceptable level of correlation. The largest (absolute) coefficient +0.28 (between PBT and TP) significant at the $1 \%$ level, is below the critical value of 0.9 (Hair et al., 2006) which indicates insignificant multicollinearity. 
17 Any potential endogeneity of TP is assessed by re-estimated model I using a 2SLS regression with an instrumental variable (IV) (Larcker \& Rusticus, 2007). Based on the Durbin-Wu-Hausman test for endogeneity the test rejects the endogeneity of TP $\chi 2=14.92$ $(\mathrm{p}=0.5304)$. The lag variable TP is considered an appropriate IV due to the short-run nature of a tax planning activities (Dyreng et al., 2008).

${ }^{18}$ Although formal tests do not indicate excessive multicollinearity, see endnote 16 .

${ }^{19}$ Result of test of significance is as follows: $\mathrm{H}_{\mathrm{O}}-8.0161=-8.8816$ not rejected $\chi 2=0.03$ $(\mathrm{p}=0.8578)$.

20 Interestingly though it does appear to moderate the relationship between earnings management and firm value.

${ }^{21}$ Result of test of significance is as follows: $\mathrm{H}_{\mathrm{O}}-2.7992=-2.5750$ not rejected $\chi 2=0.23$ $(\mathrm{p}=0.6347)$. As the sample size varies between models II and IV a more stringent test is to estimate model II using model IV sample size and then compare values of EM coefficient. This process results in the following: Ho $-2.7456=-2.5750$ not rejected $\chi 2=0.11(\mathrm{p}=$ $0.7398)$.

${ }^{22}$ A simple test of differences between the five tax component coefficient estimates indicate that TPD is significantly different from each of the other four coefficients (TLOSS, TTD, STRDIF and TUNC) and in turn these four do not differ from each other.

${ }^{23}$ Tobin's Q is computed by deflating, the amount of book value of assets plus market value of common stock minus book value of common stock minus deferred tax expense, by book value of assets. As it is now included in the dependent variable the book value of equity is then removed as an independent variable.

${ }^{24}$ Results of tests of significance between the TP coefficient (or tax component variables as in model IV) in each set of models i.e. with and without the control variables CAPINT, LEV and FS, are summarised as follows: Model I TP (including controls) = -9.1967, TP (excluding controls $)=-9.5025, \chi 2=0.01(\mathrm{p}=0.9230)$. Model II TP (including controls) $=-9.5925, \mathrm{TP}$ (excluding controls $)=-10.4004, \chi 2=0.07(\mathrm{p}=0.7987)$. Model III TP (including controls $)=$ 2.9235, TP (excluding controls $)=3.5267, \chi 2=0.00(\mathrm{p}=0.9516)$. Model IV TLOSS, TPD, TTD, STRDIF, TUNC (including controls) -1.7713, -12.3547, 7.0694, 5.6768 and -5.8766 respectively; (excluding controls) -1.3063, -12.4622, 7.7668, 2.5688 and -5.7410 respectively, $\chi 2=0.01(\mathrm{p}=0.9353), \chi 2=0.00(\mathrm{p}=0.9864)$ and $\chi 2=0.02(\mathrm{p}=0.8847)$ respectively. 
${ }^{25}$ In the interests of economy these results are not tabulated but are available from the authors upon request. 


\section{References}

Accountancy (2007). Analysis Top 60 Firms. Accountancy Magazine, available on the internet at http://www.accountancymagazine.com/Accy_Mag/Top_60_Surveys/Top60Survey2007.pdf

Accessed 21.01.2011.

Akbar, S., Stark, A. W. (2003). Deflators, net shareholder cash flows, dividends, capital contributions and estimated models of corporate valuation. Journal of Business Finance and Accounting, 30(9-10), 1211-1233.

Amir, E., Sougiannis, T. (1999). Analysts' interpretation and investors' valuation of tax carryforwards. Contemporary Accounting Research, 16(1), 1-34.

Atwood, T. J., Reynolds, J. K. (2008). The pricing of realized tax benefits from NOL carryforwards: Effect of income statement presentation. Journal of the American Taxation Association, 30(1), 1-27.

Bauman, M. P., Shaw, K. W. (2008). The usefulness of disclosures of untaxed foreign earnings in firm valuation. Journal of the American Taxation Association, 30(2), 53-77.

Belsley, D., Kuh, E., Welsch, R. E. (1980). Regression Diagnostics: Identifying Influential Data and Sources of Collinearity. New York: John Wiley and Sons.

Bernard, V. L. (1987). Cross-sectional dependence and problems in inference in marketbased accounting research. Journal of Accounting Research, 25(1), 1-48.

Chen, S., Chen, X., Cheng, Q., Shevlin, T. J. (2010). Are family firms more tax aggressive than non-family firms? Journal of Financial Economics, 95(1), 41-61.

Chen, X., Ender, P. B., Mitchell, M., Wells, C. (2005). Stata Web Books: Regression with Stata, available on the internet at www.ats.ucla.edu/stat/stata/webbooks/reg/

Accessed 21.01.2011.

Christian Aid (2009). Christian Aid Pushes for Tax Justice in War on Poverty, available on the internet at www.christianaid.org.uk/pressoffice/pressreleases/february2009/ChristianAidtax-justice-campaign.aspx Accessed 21.01.2011.

Cloyd, C. B., Mills, L. F., Weaver, C. D. (2003). Firm valuation effects of the expatriation of US corporations to tax-haven countries. Journal of the American Taxation Association, 25(S1), 87-109.

Conyon, M. J., Muldoon, M. R. (2006). The small world of corporate boards. Journal of Business Finance and Accounting, 33(9 \& 10), 1321-1343.

Derashid, C., Zhang, H. (2003). Effective tax rates and the "industrial policy" hypothesis: Evidence from Malaysia. Journal of International Accounting, Auditing and Taxation, 12(1), 45-62. 
Desai, M. A., Dharmapala, D. (2006). Corporate tax avoidance and high powered incentives. Journal of Financial Economics, 79(1), 145-179.

Desai, M. A., Dharmapala, D. (2009). Corporate tax avoidance and firm value. The Review of Economics and Statistics, 91(3), 537-546.

Dyreng, S., Hanlon, M., Maydew, E. L. (2008). Long-run corporate tax avoidance. The Accounting Review, 83(1), 61-82.

European Union (1999) Code of conduct. Harmful Tax Competition, available on the internet at http://ec.europa.eu/taxation_customs/taxation/company_tax/harmful_tax_practices/index_en. htm\#code_conduct Accessed 21.01.2011.

European Union (2004). Communication from the Commission to the Council and the European Parliament on Preventing and Combating Corporate and Financial Malpractice, available on the internet at http://ec.europa.eu/taxation_customs/resources/documents/coc_en.pdf Accessed 21.01.2011.

Financial Times (2010). Treasury Condemns £42bn Tax Gap. V Houlder. September 16 2010, available on the internet at www.ft.com/cms/s/0/63255cbc-c1c5-11df-9d90$\underline{00144 f e a b 49 \mathrm{a}, \mathrm{s} 01=1 . h t m l \# a x z z 1 B T 10 L U V C}$ Accessed 21.01.2011

Firth, M., Tam, M., Tang, M. (1999). The determinants of top management pay. Omega, 27(6), 617-635.

Florackis, C. (2008). Agency costs and corporate governance mechanisms: Evidence for UK firms. International Journal of Managerial Finance, 4(1), 37-59.

Frank, M. M., Lynch, L. J., Rego, S. O. (2009). Tax reporting aggressiveness and its relation to aggressive financial reporting. The Accounting Review, 84(2), 467-496.

Freedman, J., Loomer, G., Vella, J. (2007). Moving Beyond Avoidance? Tax Risk and the Relationship between Large Business and HMRC. Report of the Oxford University Centre for Business Taxation, available on the internet at http://denning.law.ox.ac.uk/tax/documents/Movingbeyondavoidance.pdf Accessed 21.01.2011.

Goergen, M., Renneboog, L. U. C. (2001). Strong managers and passive institutional investors in the UK. In Barca, F. and Becht, M. (Eds.) The Control of Corporate Europe (pp. 259-284). Oxford University Press.

Gupta, S., Newberry, K. (1997). Determinants of the variability in corporate effective tax rates: Evidence from longitudinal data. Journal of Accounting and Public Policy, 16(1), 1-34.

Hair, J. F., Black, W. C., Babin, B. J., Anderson, R. E., Tatham, R. L. (2006). Multivariate Data Analysis, 6th ed. New Jersey: Pearson Education Inc. 
Haniffa, R., Hudaib, M. (2006). Corporate governance structure and performance of Malaysian listed companies. Journal of Business Finance and Accounting, 33(7 and 8), 10341062.

Hanlon, M. (2003). What can we infer about a firm's taxable income from its financial statements? National Tax Journal, 56(4), 831-864.

Hanlon, M. (2005). The persistence and pricing of earnings, accruals, and cash flows when firms have large book-tax differences. The Accounting Review, 80(1), 137-166.

Hanlon, M., Slemrod, J. B. (2009). What does tax aggressiveness signal? Evidence from stock price reactions to news about tax shelter involvement. Journal of Public Economics, 93(1-2), 126-141.

Hart, O. (1995). Corporate governance: Some theory and implications. The Economic Journal, 105(430), 678-689.

Hartnett, D. (2009). UK tax administration. Tax Journal. 22 June 2009, 986, 8 -10.

Healy, P. M. (1985). The effect of bonus schemes on accounting decisions. Journal of Accounting and Economics, 7(1-3), 85-107.

Henderson Global Investors. (2005). Tax, Risk and Corporate Governance. Sustainable and Responsible Investment Reports, available on the internet at http://www.henderson.com/content/sri/publications/reports/taxriskcorporategovernance.pdf Accessed 21.01.2011.

HMRC. (2006). Disclosure of Tax Avoidance Schemes, available on the internet at www.hmrc.gov.uk/aiu/summary-disclosure-rules.htm Accessed 21.01.2011.

HMRC. (2007). Approach to Compliance Risk Management for Large Business, available on the internet at www.hmrc.gov.uk/budget2007/large-business-riskman.pdf Accessed 21.01.2011.

HMRC (2010). Measuring Tax Gaps 2010, available on the internet at http://www.hmrc.gov.uk/stats/measuring-tax-gaps-2010.htm.pdf Accessed 21.01.2011

HM Treasury. (2010). Written Ministerial Statement. Anti-Avoidance, available on the internet at www.hm-treasury.gov.uk/d/wms_antiavoidance_061210.pdf Accessed 21.01.2011

Holland, K. (1998). Accounting policy choice: The relationship between corporate tax burdens and company size. Journal of Business Finance and Accounting, 25(3 \& 4), 265-288.

Horton, J. (2008). The value relevance of 'realistic reporting': Evidence from UK life insurers. Accounting and Business Research, 37(3), 175-197.

IASB. (2010). International Accounting Standard 12 "Income Taxes", available on the internet at www.ifrs.org Accessed 21.01.2011. 
Jensen, M. C., Meckling, W. H. (1976). Theory of the firm: Managerial behavior, agency costs and ownership structure. Journal of Financial Economics, 3(4), 305-360.

Larcker, D. F., Rusticus, T. O. ( 2007). Endogeneity and Empirical Accounting Research. European Accounting Review, 16(1) 207-215

Liu, L. S., Stark, A. W. (2009). Relative performance evaluation in board cash compensation: UK empirical evidence. The British Accounting Review, 41(1), 21-30.

Maydew, E. L., Shackelford, D. A. (2007). The changing role of auditors in corporate tax planning. In Auerbach, A. J., Hines, J. R. and Slemrod, J. (Eds.) Taxing Corporate Income in the 21st Century (pp. 307-337). Cambridge University Press.

McKnight, P. J., Weir, C. (2009). Agency costs, corporate governance mechanisms and ownership structure in large UK publicly quoted companies: A panel data analysis. Quarterly Review of Economics and Finance, 49(2), 139-156.

Mills, L. F., Erickson, M., Maydew, E. L. (1998). Investment in tax planning. The Journal of the American Taxation Association, 20(1), 1-20.

National Audit Office (2007). HM Revenue and Customs: Management of Large Business Corporation Tax, HC 614 Session 2006-2007 ed. London: Stationery Office.

O'Hanlon, J., Taylor, P. (2007). The value relevance of disclosures of liabilities of equityaccounted investees: UK evidence. Accounting and Business Research, 37(4), 267-284.

O'Hanlon, J. F., Pope, P. F. (1999). The value-relevance of UK dirty surplus accounting flows. The British Accounting Review, 31(4), 459-482.

OECD. (1998). Harmful Tax Competition: An Emerging Global Issue, available on the internet at www.oecd.org/dataoecd/33/0/1904176.pdf Accessed 21.01.2011

OECD. (2008) Study into the Role of Tax Intermediaries, available on the internet at www.oecd.org/dataoecd/28/34/39882938.pdf Accessed 21.01.2011.

OECD. (2009). Building Transparent Tax Compliance by Banks, available on the internet at www.oecd.org/ctp/ta/banks Accessed 21.01.2011

Oxfam. (2009). Tax Haven Crackdown could Deliver \$120bn a Year to Fight Poverty Oxfam, available on the internet at www.oxfam.org.uk/applications/blogs/pressoffice/?p=3912 Accessed 21.01.2011.

Petersen, M. A. (2009). Estimating standard errors in finance panel data sets: Comparing approaches. Review of Financial Studies, 22(1), 435-480.

Pett, M. A., Lackey, N. R., Sullivan, J. J. (2003). Making Sense of Factor Analysis: The use of Factor Analysis for Instrument Development in Health Care Research. London: Sage Publications. 
Phillips, J., Pincus, M., Rego, S. O. (2003). Earnings management: New evidence based on deferred tax expense. The Accounting Review, 78(2), 491-521.

Porcano, T. (1986). Corporate tax rates: Progressive, proportional, or regressive. Journal of the American Taxation Association, 7(2), 17-31.

Rees, W. P. (1997). The impact of dividends, debt and investment on valuation models. Journal of Business Finance and Accounting, 24(7 \& 8), 1111-1140.

Rego, S. O. (2003). Tax-avoidance activities of U.S. multinational corporations. Contemporary Accounting Research, 20(4), 805-833.

Shackelford, D. A., Shevlin, T. (2001). Empirical tax research in accounting. Journal of Accounting and Economics, 31(1-3), 321-387.

Slemrod, J. (2004). The economics of corporate tax selfishness. National Tax Journal, 57(4), 877-899.

Stark, A. W., Thomas, H. M. (1998). On the empirical relationship between market value and residual income in the UK. Management Accounting Research, 9(4), 445-460.

Stewart, J. C. (1981). Company tax - Effective tax rates on profits. Journal of the Statistical and Social Inquiry Society of Ireland, 24(3), 101-134.

Swenson, C. (1999). Increasing stock market value by reducing effective tax rates. Tax Notes, June 7, 1503-1505.

Tailby, C. (2009). Tax avoidance - then and now. Tax Journal. 22 June 2009, 986, 23 -25.

The Corporate Register (various years) HS Financial Publishing. London.

The Guardian. (2009). Firms' Secret Tax Avoidance Schemes Cost UK Billions: Investigation into the Complex and Confidential World of Tax. Tax Gap Reporting, available on the internet at http://www.guardian.co.uk/business/2009/feb/02/tax-gap-avoidance Accessed 21.01.2011.

Trade Union Congress. (2009). The Missing Billions the UK Tax Gap (2009) Touchstone Pamphlets, available on the internet at www.tuc.org.uk/touchstone/Missingbillions/lmissingbillions.pdf Accessed 21.01.2011.

Weisbach, D. A. (2002). Ten truths about tax shelters. Tax Law Review, 55(2), 215-253.

Wilson, R. (2009). An examination of corporate tax shelter participants. The Accounting Review, 84(3), 969-999.

Zahra, S. A., Pearce, J. A. (1989). Boards of directors and corporate financial performance: A review and integrative model. Journal of Management, 15(2), 291-334.

Zimmerman, J. L. (1983). Taxes and firm size. Journal of Accounting and Economics, 5(2), 119-149. 
Table 1: Corporate Governance Measures

\begin{tabular}{|c|c|c|}
\hline Mechanism & Variable & Measure \\
\hline \multirow{2}{*}{$\begin{array}{l}\text { Ownership } \\
\text { structure }\end{array}$} & Director ownership (DOWN) & Percentage of shares held by directors \\
\hline & Institutional ownership (IOWN) & $\begin{array}{l}\text { Percentage of shares held by substantial } \\
\text { institutional shareholders }\end{array}$ \\
\hline \multirow{3}{*}{$\begin{array}{l}\text { Board } \\
\text { structure }\end{array}$} & Board size (BSIZE) & Number of directors serving the board \\
\hline & Non-executive directors (NED) & $\begin{array}{l}\text { Percentage of non-executive directors to } \\
\text { total number of directors on the board }\end{array}$ \\
\hline & Multi-directorship (MDIR) & $\begin{array}{l}\text { Percentage of directors who serve more } \\
\text { than one board to total number of } \\
\text { directors }\end{array}$ \\
\hline \multirow[t]{2}{*}{$\begin{array}{l}\text { Compensation } \\
\text { structure }\end{array}$} & Executive salary (SAL) & $\begin{array}{l}\text { Total salary paid to executive directors } \\
\text { (scaled by beginning book value of } \\
\text { equity) }\end{array}$ \\
\hline & Option or bonus (BODUM) & $\begin{array}{l}\text { Dummy measure of option or bonus, } 1 \text { if } \\
\text { option or bonus has been paid, } 0 \\
\text { otherwise }\end{array}$ \\
\hline
\end{tabular}


Table 2: Factor analysis - Corporate Governance

Panel A: Matrix Characteristics

Overall KMO test statistic: 0.6115

Bartlett's test of sphericity: $\chi 2=607.680 * * *$

Matrix determinate: 0.3530

*** indicates significance at $1 \%$ level.

Panel B: Pearson Correlation Matrix and Kaiser-Meyer-Olkins statistics

$\mathrm{n}=588$ DOWN IOWN BSIZE NED MDIR SAL BODUM

DOWN $\quad 0.611$

IOWN $\quad-0.275 * * * \quad 0.522$

BSIZE $\quad-0.044 \quad-0.146^{* * *}$

NED $\quad-0.204 * * * \quad 0.127 * * *$

MDIR $\quad-0.295^{* *}$

SAL $\quad 0.1519 * * *$

BODUM $-0.330 * * *$

0.038

$\begin{array}{rrr}0.654 & & \\ 0.154 * * * & 0.593 & \\ 0.196 * * * & 0.609 * * * & 0.597 \\ -0.184 * * * & -0.368 * * * & -0.250 * * * \\ -0.071 * & 0.1658 * * * & 0.119 * * *\end{array}$

$0.146^{* * *}$

$0.119 * * * \quad-0.112 * * *$

0.6405

Individual Kaiser-Meyer-Olkins statistics are in italics on the diagonal Correlation coefficients on off-diagonal.

Panel C: Rotated Factor Loadings

Items

Factor 1

Factor 2

DOWN

$-0.344$

$-0.039$

$-0.6507 \#$

IOWN

$0.505 \#$

$0.698 \#$

BSIZE

$0.794 \#$

$-0.424$

NED

$0.785 \#$

0.166

MDIR

$-0.631 \#$

0.126

SAL

0.168

0.026

BODUM

\# Indicates extracted items for each factor.

$0.631 \#$

$* * *, * *$ and $*$ indicate significance at $1 \%, 2.5 \%$ and $5 \%$ levels respectively. 
Table 3: Variables

\begin{tabular}{|c|c|c|}
\hline Variable & Description (expected sign) & Measurement \\
\hline $\mathrm{MVE}_{+3 \text { months }}$ & Market value of equity & Market value of equity \\
\hline BVE & Book value of equity $(+)$ & Book value of equity \\
\hline PBT & Profit before tax $(+)$ & Profit before tax \\
\hline $\mathrm{TP}$ & Tax planning $( \pm)$ & $(\mathrm{STR}-\mathrm{ETR}) * \mathrm{PBT}$ \\
\hline TLOSS & Tax losses $( \pm)$ & Tax loss related reconciling items \\
\hline TPD & Permanent differences $( \pm)$ & Permanent difference reconciling items \\
\hline TTD & Timing differences $( \pm)$ & Timing difference reconciling items \\
\hline STRDIF & Statutory rate differential $( \pm)$ & UK/overseas tax differential reconciling items \\
\hline TUNC & Unclassified items $( \pm)$ & Unclassified reconciling items \\
\hline $\mathrm{CC}$ & Capital contribution $(+)$ & $\begin{array}{l}\text { Net proceed from sales or issues of common and } \\
\text { preferred shares }\end{array}$ \\
\hline EM & Earnings management (-) & $\begin{array}{l}\text { Profit before tax - Cash flow from operating } \\
\text { activities }\end{array}$ \\
\hline CAPINT & Capital intensity $( \pm)$ & Gross machinery and equipment/Total assets \\
\hline LEV & Leverage $(+)$ & Long term debt/Total assets \\
\hline DIV & Dividend $(+)$ & Dividends Per Share/Earnings Per Share*100 \\
\hline FS & Foreign sale $( \pm)$ & Percentage of foreign sales over total net sales \\
\hline NED & Corporate governance I (+) & $\begin{array}{l}\text { Proportion of non-executive directors on the board } \\
\text { of company }\end{array}$ \\
\hline IOWN & Corporate governance II (+) & Percentage Institutional ownership \\
\hline INDDUM & Industry dummy $( \pm)$ & $\begin{array}{l}\text { Coded } 1 \text { for each particular industry classification, } 0 \\
\text { otherwise }\end{array}$ \\
\hline
\end{tabular}


Table 4: Sample Selection Process

\begin{tabular}{lrr} 
Details & $\begin{array}{c}\text { Number of } \\
\text { Observations }\end{array}$ & $\begin{array}{r}\text { Number of } \\
\text { Companies }\end{array}$ \\
\hline $\begin{array}{l}\text { Public listed companies (listed throughout the period) } \\
\text { Finance companies }\end{array}$ & 1006 \\
Not available in Datastream & $(580)$ \\
At least one year of annual report is not available & $(32)$ \\
Accounting period of more than 12 months & $(59)$ \\
Insufficient effective tax rate reconciliation data & $(4)$ \\
Negative book value of equity & & $(29)$ \\
"Zero" sales & & $(24)$ \\
Extreme value of effective tax rates (ETR>1) & $(1)$ \\
& & $(19)$ \\
Negative profit before tax & 774 & 258 \\
Negative tax charge & $(76)$ & \\
Unbalance data & $(22)$ & \\
Initial sample & $(88)$ &
\end{tabular}


Table 5: Descriptive Statistics

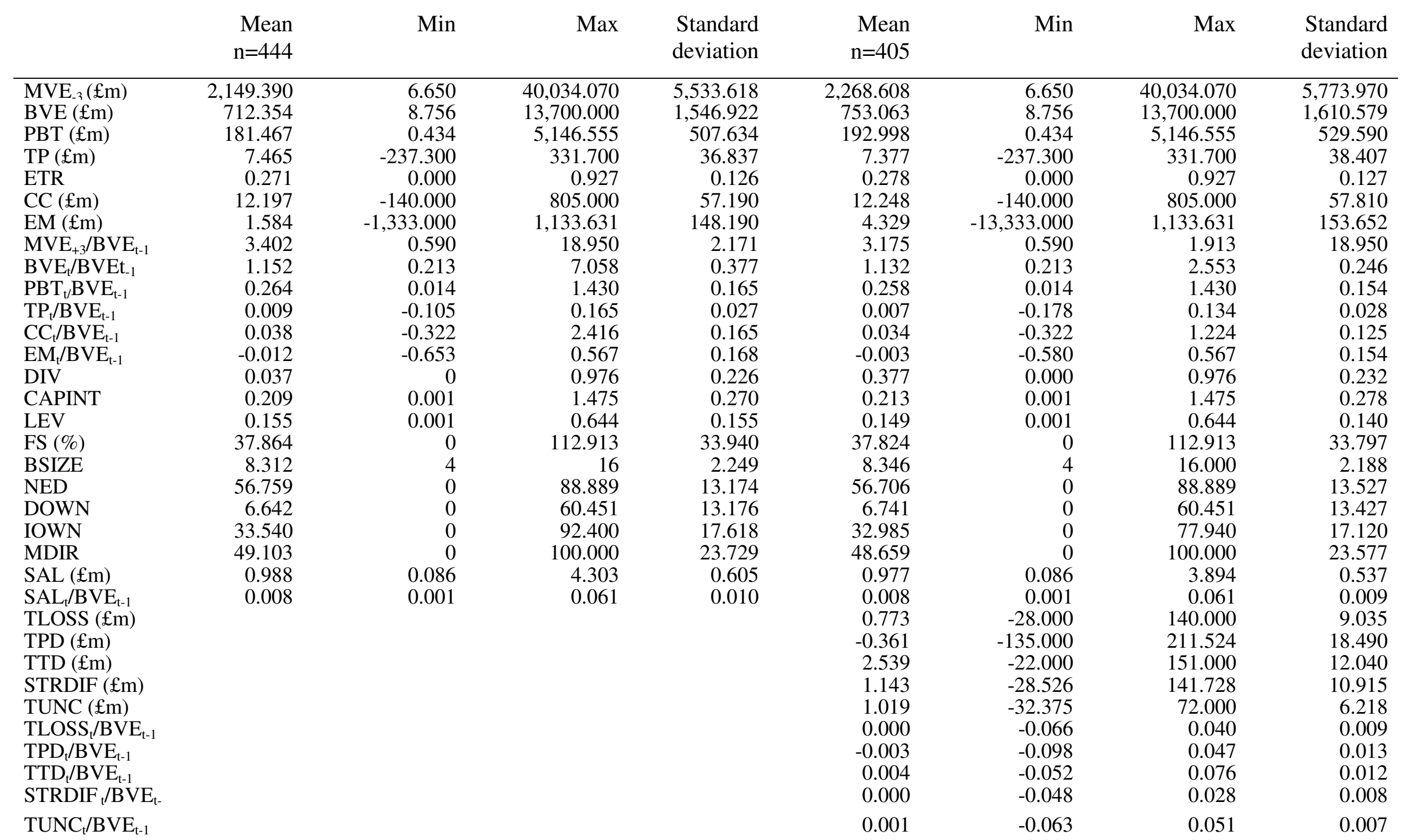


Table 6: Regression estimations -Models I, II, III and IV

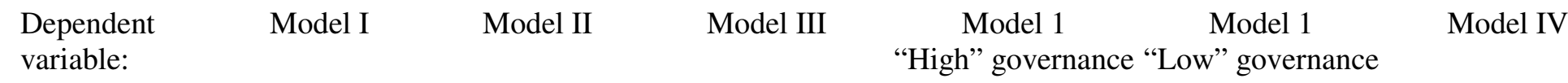

$\mathrm{MVE}_{\mathrm{t}+3 \mathrm{months}}$

\begin{tabular}{lrrrrr}
\hline BE & 1.0814 & 1.1167 & 1.1286 & 1.2592 & 0.6055 \\
& $4.53 * * *$ & $4.68 * * *$ & $4.83 * * *$ & $3.88 * * *$ & 1.47 \\
PBT & 10.0106 & 10.0020 & 10.0312 & 9.8773 & 10.7235 \\
& $17.00^{* * *}$ & $16.79 * * *$ & $16.87 * * *$ & $16.12 * * *$ & $10.92 * * * *$ \\
TP & -9.1967 & -9.5925 & 2.9235 & -8.0161 & -8.8816 \\
& $-2.91 * * *$ & $-3.03 * * *$ & 0.30 & $-1.76^{*}$ & $-2.03 * *$
\end{tabular}

TLOSS

TPD

$-0.31$

$-12.3547$

$-1.96 * *$

7.0694

1.47

5.6768

0.69

$-5.8766$

$-0.54$

0.0075

1.44

$-0.0083$

$-0.0074-0.0070$

$-2.10 *$

TP*NED

$-0.1681$

$-1.07$

$-0.0817$

$-0.56$

TP*IOWN

0.0731

0.16

$-0.0238$

$-0.03$

0.4513

0.3319

0.38

0.22

$-2.7651$

$-2.8076$

$-2.7992$

$-6.42 * * *$

$-6.31 * * *$

$-0.9329$

$-5.15 * * *$

0.89

0.71

$-6.19 * * *$

$-2.9649$

$-0.5163$

$-0.5175$

$-2.96 * * *$

$-2.96 * * *$

$-0.3598$

$-4.88 * * *$

$-2.5750$

CAPINT

$-0.2923$

$-2.95 * * *$

$-0.7671$

$-1.69 *$

$-2.22 *$

$-5.46 * * *$

$-0.4862$

0.0247

$-1.0018$

$-0.4714$

$-0.4577$

$-1.01$

$-0.0002$

$-0.0003$

0.04

$-1.62$

$-0.0006$

$-0.0007$

$-0.23$

0.0096

0.0057

0.0058

$-0.22$

$2.78 * * *$

0.0017

$3.48 * * *$

$-2.44 * * *$

$-0.2551$

$-0.61$

0.0026

1.51

$2.84 * * *$

0.62

0.0059

$-0.3715$

0.2259

$2.96 * * *$

$-0.0878$

0.36

$-0.1855$

$-1.05$

$-0.19$

$-0.41$

$64.34 \% \quad 64.70 \%$

$61.17 \%$

$71.66 \%$

$58.84 \%$

444

222

405

$\mathrm{N}$

$444 \quad 444$

222

$838.15(16) * * *$

465.98 (16) *** $363.70(22) * * *$

$34.63(16) * * *$

$55.13(16) * * * \quad 77.60(22) * * *$

Breusch-Pagan $82.98(16) * * * \quad 83.95(18) * * * \quad 84.70(20) * * *$

1. Figures in italics represent cross-section clustered Eicker-Huber-White adjusted t-statistics. $2 . * * *, * *$ and $*$ indicate
significance at $1 \%, 2.5 \%$ and $10 \%$ respectively (single or two tailed respectively). 3. Industry dummy coefficients not reported in interests of economy. 


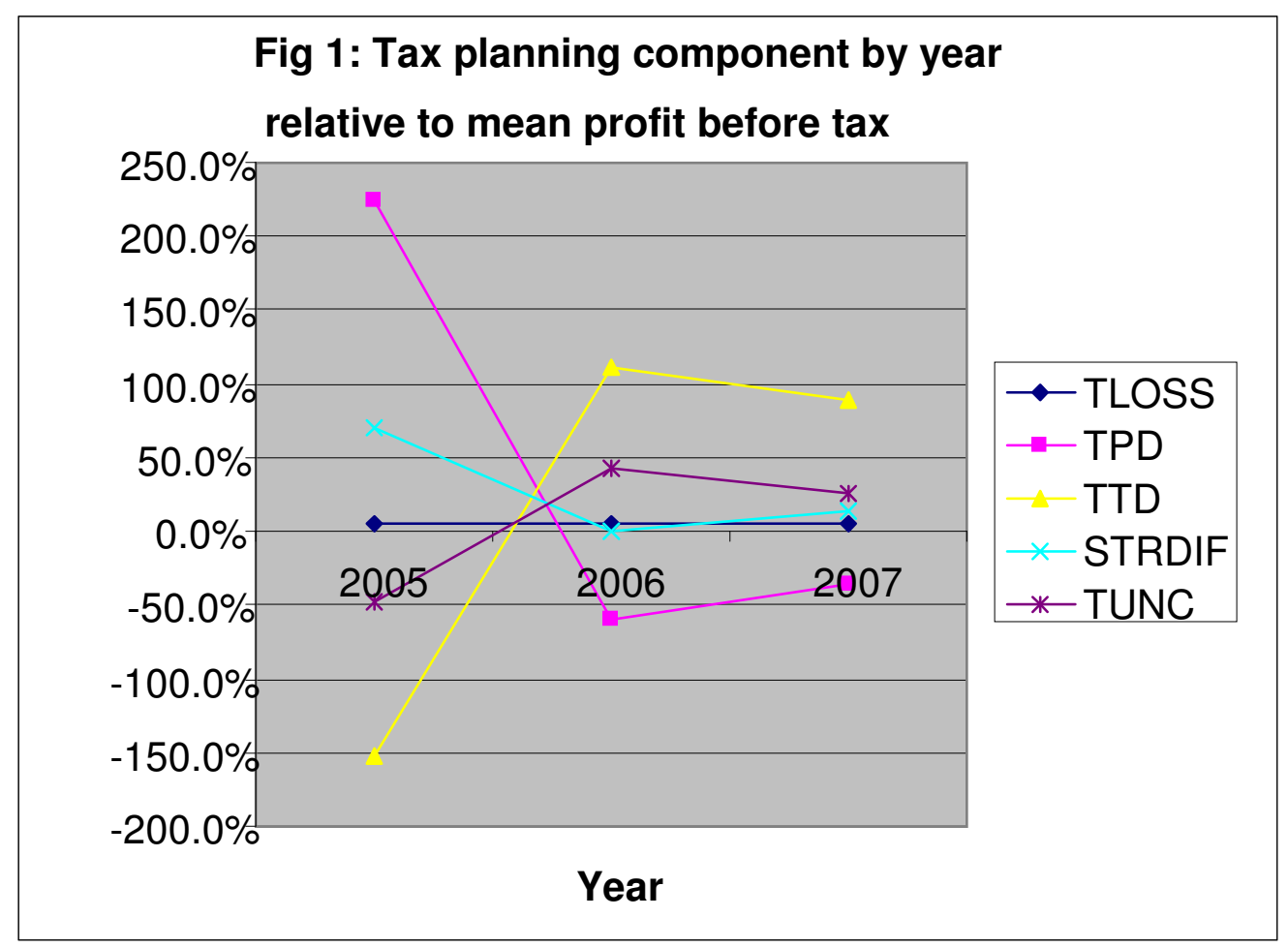

